\title{
Arts-Aided Recognition of Citizens' Perceptions for Urban Open Space Management
}

\author{
Sari Suomalainen ${ }^{1, * \mathbb{D}}$, Helena Kahiluoto ${ }^{1}$, Anne Pässilä ${ }^{2}$, Allan Owens ${ }^{3}$ and Clive Holtham ${ }^{4}$ \\ 1 Sustainability Science, School of Energy Systems, LUT University, 53851 Lappeenranta, Finland; \\ helena.kahiluoto@lut.fi \\ 2 School of Engineering Science, Industrial Management, Lahti Campus, LUT University, 15210 Lahti, Finland; \\ anne.passila@lut.fi \\ 3 Centre for Research into Education, Creativity and the Arts through Practice, University of Chester, \\ Chester CH1 4BJ, UK; a.owens@chester.ac.uk \\ 4 Faculty of Management, Bayes Business School, University of London, London EC1Y 8TZ, UK; \\ c.w.holtham@city.ac.uk \\ * Correspondence: sari.suomalainen@student.lut.fi; Tel.: +358-050-574-3617
}

\section{check for}

Citation: Suomalainen, S.; Kahiluoto, H.; Pässilä, A.; Owens, A.; Holtham,

C. Arts-Aided Recognition of Citizens' Perceptions for Urban Open Space Management. Sustainability 2022, 14, 135. https://doi.org/ $10.3390 /$ su14010135

Academic Editors: Raúl RomeroCalcerrada, Javier Cabello, Manuel Pacheco-Romero and Koldo Trapaga Monchet

Received: 15 November 2021 Accepted: 14 December 2021 Published: 23 December 2021

Publisher's Note: MDPI stays neutral with regard to jurisdictional claims in published maps and institutional affiliations.

Copyright: (c) 2021 by the authors. Licensee MDPI, Basel, Switzerland. This article is an open access article distributed under the terms and conditions of the Creative Commons Attribution (CC BY) license (https:// creativecommons.org/licenses/by/ $4.0 /)$.

\begin{abstract}
Urban open spaces of local natural environments can promote the health and well-being of both ecosystems and humans, and the management of the urban spaces can benefit from knowledge of individuals' / citizens' perceptions of such environments. However, such knowledge is scarce and contemporary inquiries are often limited to cognitive observations and focused on built environmental elements rather than encouraged to recognize and communicate comprehensive perceptions. This paper investigates whether arts-based methods can facilitate recognition and understanding perceptions of urban open spaces. Two arts-based methods were used to capture perceptions: drifting, which is a walking method, and theatrical images, which is a still image method and three reflective methods to recognize and communicate the perceptions. The results show related sensations and perceptions enabled by arts-based methods comparing them to a sticker map method. The main findings were perceptions, which included information about human-environment interaction, about relations to other people and about 'sense of place' in urban open spaces. The hitherto unidentified perceptions about urban open space were associations, metaphors and memories. The methods used offer initial practical implications for future use.
\end{abstract}

Keywords: urban open space; arts-based methods; perceptions; human-environment interaction; sustainable transition

\section{Introduction}

The social and cultural dimensions of sustainability-the 'people'-are seen as increasingly important, as articulated in the goals set in the UN's 2030 Agenda for Sustainable Development [1,2]. The human dimensions can be in a more or less positive interplay with environmental sustainability. Urban open spaces are mainly unbuilt environments comprising green spaces, urban blue and brown areas and hard-surfaced grey areas [3] (p. 12) for this interplay. Parks are known as publicly accessible urban open spaces and they have reflected societal values of each era [4] (p. 201). To allow urban open spaces to facilitate connecting humans to ecosystems [5] in a way that increases sustainability [6] it is, however, important to know how people value, perceive [7] and feel [8] about such environments. While new approaches to meet new views and gain subjective information about urban open spaces [9] are desired, it is crucial to think about how to understand communities and stakeholders from diverse backgrounds, giving them a bottom-up voice enhancing dialogue with the urban open space management organizations.

Rapid global changes are imposing stress on the natural environment, which has led to a need for intervention not only via environmental policy making but also individual actions $[10,11]$. It has been shown that the motivation and commitment towards sustainable 
lifestyles and cultures depends on people's connection with nature, i.e., their feelings for nature as represented by urban open spaces in the modern society $[12,13]$. Furthermore, behavioral change demands not only cognition but also passion and emotion [12], and the long-term effectiveness of interventions can be facilitated by acknowledging subjective expressions and emotive statements of people involved [14].

Perceptions imply subjective information based on sensory experience, i.e., perceptions include sense data, which is immediate awareness of a perception [15]. Human sensations assimilate information from the environment and the information is processed by the human brain into subjective perceptions, different for different people [16] (p. 20) also regarding perceptions about landscape, which provide subjective understanding [17]. Jacobs [18] (p. 121) defines a landscape perception as a prerequisite mode of experiencing that is followed by thinking, imagining and dreaming which are more related to use of knowledge. Perceptual experience of landscapes is studied by expert-led landscape identity assessments $[19,20]$, which supplement the spatial and cultural dimensions. The assessments tend to emphasize four senses (vision, hearing, smell and touch); however, experiencing an entire environment requires continuous use of all five senses including also the taste sense [21], [22] (p. 105). In addition, the touch sense can be divided into the haptic sense and the kinesthetic sense, the latter emphasizing the body's relation with the environment [21] (p. 40).

Subjective information about urban open spaces is seldom provided by contemporary inquiries. While studies utilizing quantitative on-site methods in urban natural areas have contributed knowledge about human reflections about environment [23-25], personal and emotional knowledge is still lacking. Consequently, perceptions have not been captured. Arts-based qualitative research methods utilize art forms to enable, recognize and communicate perceptions [26] (pp. 10, 164), [27] (p. 4), [28] (p. 6). Those methods embrace the cognitive and bodily elements together with the less tangible personal, emotional and sensory-based reflections [29] (p. 9), [30] and meanings [26] (p. 168); these cannot be captured by cognitive maps enabling perceptions about spatial qualities [31,32] or by measurements and surveys [12]. Consequently, arts-based methods might recognize the influences on people's behaviors and actions [33-35] thus having the capacity to foster change.

The objective of this study was to capture citizens' perceptions about urban open spaces implying the subjective meanings and representations assigned [14] [21] (p. 40). Such knowledge can inform management of urban open spaces to enhance positive humannature interactions, as the perceptions that people have about those spaces are not yet known. Consequently, the purpose of the paper is to answer the following research question: What kind of perceptions about urban open spaces do arts-based methods enable?

\section{Materials and Methods}

\subsection{Area Descriptions}

This study was conducted in two urban parks in southern Finland. The parks were the Pikku-Vesijärvi Park area in the center of Lahti city and the Rautkallio Park in a dwelling zone of Vantaa city (Figure 1). These parks were under development planning, and therefore the cities had undertaken to implement the workshops in these parks. This provided two parks and three different workshops for this study. The workshop in the Rautkallio Park utilized a different arts-based method than Pikku-Vesijärvi Park workshops. The PikkuVesijärvi Park area is a center park on the lakeshore. It comprises the landscape park with blue and hard-surfaced grey areas and wooded adjacent area Lanu Park. Rautkallio Park in Vantaa is situated in the inner core of the Finnish capital region. The activity areas such as play areas and children's playgrounds are hard-surfaced grey areas whereas other parts are man-made green areas and natural wooded areas. 

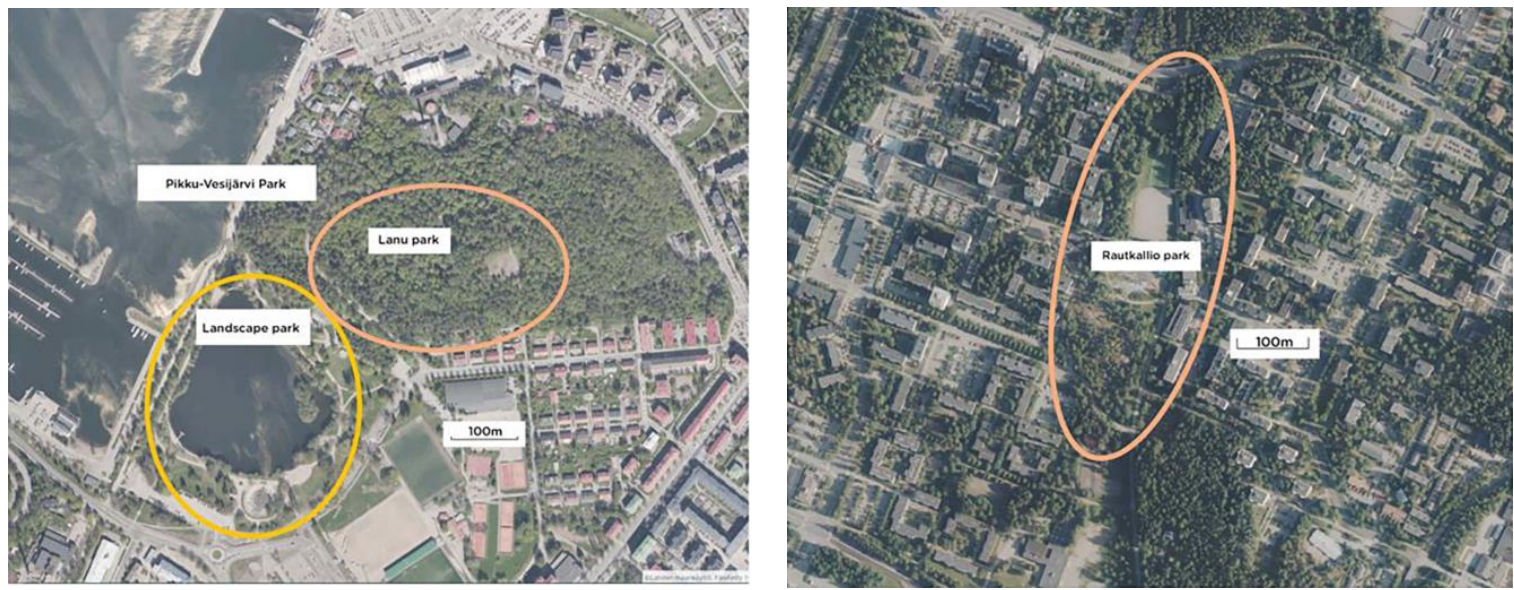

Figure 1. The two urban parks in this study. (a) Pikku-Vesijärvi Park area is a center park in Lahti (b) Rautkallio Park is a dwelling zone park in Vantaa [36].

\subsection{Methods for Capturing and Reflecting}

The two arts-based methods for capturing perceptions used in this study were drifting and the theatrical image method. Two methods were used, because different methods may lead to different types of perceptions.

Drifting, or dérive [37,38] (pp. 53-55) emphasizes walking and wandering, which lead to the embodiment of an experience based on movement and touch of ground [39]. The concept of psychogeography expressing people's emotions and behavior was further developed by the situationist movement since 1958 [40] and currently drifting is considered to require reflections $[41,42]$. Thus, this study of two urban parks was concerned with how people read their environment and how this reading inspires them in verbal expressions and performative narratives. The method provides the experience of "being lost":

"The letting go of work and

leisure activities in order to

... let themselves be drawn by

the attractions of the terrain and

the encounters they find there."

(Debord)

The other method used, the theatrical images method, is based on Augusto Boal's performative technique of image theatre [43] and it has been applied in the context of organizational development [44,45], where the still images (Figure 2) facilitated dialogue and reflexivity $[45,46]$. The use of theatrical images has been expanded to evoke embodied experiences [46]. In this work a sample of 15 images were used.

The arts-based methods, drifting or theatrical images were combined with the mode of reflection in order to allow participants to articulate or express themselves. The modes of reflection used in this study were (1) recorded conversations, (2) photos and text, and (3) written stories.

\subsection{A Sticker Map as a Reference Method}

In Pikku-Vesijärvi in 2017, the workshop was the first one, which utilized arts-based methods, and therefore also a sticker map method (Figure 2) was offered. The aim was to provide an alternative to participants who may not feel comfortable with the use of arts-based methods in a public open workshop. The sticker map method is a non-arts-based method that still allows artefacts to be used such as an areal photomap, stickers, and a facilitated conversation with participants. This participatory method enables place related expressions and permits frictions between participants [47]. In this study, the sticker notes with statements, a sticker map, were used as a reference method (Figure 2). 


\subsection{Data Collection}

The three workshops were organized in the two parks in 2017 and 2018. Two of the workshops took place in Pikku-Vesijärvi Park area in Lahti and one workshop in Rautkallio Park in Vantaa. Invitations to join the workshops were published in local newspapers in Finnish. The invitations were entitled: "An invitation to develop your own park story". Additionally, social media were also used, in collaboration with the cities, to promote the workshops.

The participants represented all age groups: young people, adults and pensioners. In the city center park in Lahti, participants were daily visitors and citizens staying outside the neighborhood, inspired by the invitation. In the dwelling zone park in Vantaa, the participants were staying in the neighborhood. No demographic information was collected to keep the threshold for participation as low as possible. Participants were asked to sign permission to participate in the experiment. There were no participants under 15 year old and no known risks were ascertained in this study.
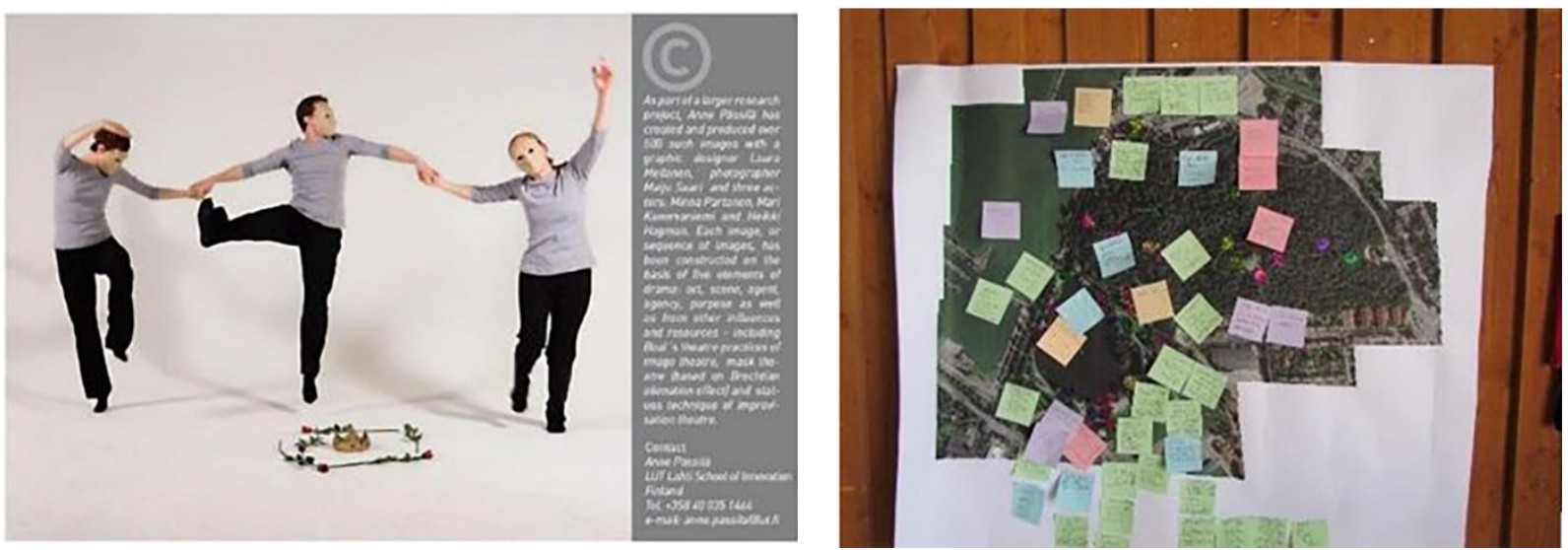

Figure 2. (a) Example of one of the 15 theatrical images [44] and (b) the sticker map as a reference method were used in the workshops.

\subsubsection{Pikku-Vesijärvi Park Area 2017}

Altogether 11 people took part in the non-stop workshops in 2017 in Pikku-Vesijärvi Landscape Park. The workshop was offered from 10.00-14.00. Participants were informed about the drifting method and the reflection session of interviews. The walk/drift was instructed to take 15-30 min and during that time they were just to explore the environment freely. The reflection session of 5-10 min was a conversation based on a couple of questions: "What did you find?" "How did you feel?" The reflections were recorded.

The sticker map was used by 43 participants who had no time to take part in the workshop or they felt more comfortable with this method. The participants were young people, adults and pensioners. Our research team members facilitated the conversations and participants used stickers to express their thoughts putting them at particular places on the map.

\subsubsection{Rautkallio Park 2017}

The non-stop workshop was organized from 11.00-15.00 in the Rautkalliopark in Vantaa and it was visited by 15 people. The researchers had a visible stand at the corner of the park and all visitors were told about the aim of collecting experiences and perceptions about the park. Three of the visitors chose to use theatrical images whereas others wanted to leave short feedback comments. The feedback comments were forwarded to the representatives of the city. Two participants chose three theatrical images cards of the sample of 15 and one participant chose one. The reflections were recorded. 


\subsubsection{Pikku-Vesijärvi Park Area 2018}

The final workshop was organized in the Pikku-Vesijärvi Park area in the Lanu Park in which 15 people took part. They were invited beforehand and therefore all the instructions could be given at the same time to all participants. This workshop took place from 16.00-18.00 including the start with instructions and the closing with the reflection sessions. The first participants were instructed to walk freely around Lanu Park for 15-30 min. Instead of interactive conversations, the reflections were in the form of individual meanings being given based on photos and text. This meant that the participants shared the photos and related text to a given e-mail address after the drifting. Additionally, the same participants used the mode of reflection to write "a letter to myself" which resembled a story. The paper and envelopes were provided, and the participants used 20-30 min to write reflections. This workshop produced two modes of reflections.

\subsection{Data}

The data based on four combinations of the two arts-based methods to capture perceptions and three arts-based methods of reflection were produced by a total of 29 different participants. In Pikku-Vesijärvi/Lanu Park the same 15 participants used two different reflection methods (Table 1 ).

Table 1. Field experimentation in the three park workshops in 2017-2018. The methods included a method of capturing and a method of reflection (1) conversations, (2) photos and text and (3) written stories. The sticker map method represented a (non-arts-based) reference method.

\begin{tabular}{|c|c|c|c|c|c|}
\hline Methods & Workshops & Informants & Time & Data & Sticker Map \\
\hline $\begin{array}{l}\text { Capturing: drifting } \\
\text { Reflecting: } \\
\text { conversation }\end{array}$ & $\begin{array}{l}\text { Pikku- } \\
\text { Vesijärvi/Landscape Park } \\
2017\end{array}$ & $\begin{array}{l}N=11 \\
\text { duration } \\
20-40 \mathrm{~min} / \text { informant }\end{array}$ & $\begin{array}{l}10.00-14.00 \\
4 \mathrm{~h}\end{array}$ & $\begin{array}{l}\text { (1) recorded } \\
\text { conversations, duration } \\
3-5 \mathrm{~min} / \text { informant }\end{array}$ & $\begin{array}{l}43 \text { sticker notes } \\
\text { about the park by } \\
18 \text { informants }\end{array}$ \\
\hline $\begin{array}{l}\text { Capturing: theatrical } \\
\text { images } \\
\text { Reflecting: } \\
\text { conversation }\end{array}$ & $\begin{array}{l}\text { Rautkallio } \\
\text { Park } 2017\end{array}$ & $\begin{array}{l}N=3 \\
\text { duration } 20 \\
\text { min/informant }\end{array}$ & $\begin{array}{l}11.00-15.00 \\
4 \mathrm{~h}\end{array}$ & $\begin{array}{l}\text { (1) recorded } \\
\text { conversations duration } \\
5 \mathrm{~min} / \text { informant }\end{array}$ & no \\
\hline $\begin{array}{l}\text { Capturing: drifting } \\
\text { Reflecting: photos/text }\end{array}$ & $\begin{array}{l}\text { Pikku- } \\
\text { Vesijärvi/LanuPark } \\
2018\end{array}$ & $\begin{array}{l}N=15 \\
\text { duration } 2 \\
\mathrm{~h} / \text { informant }\end{array}$ & $\begin{array}{l}16.00-18.00 \\
2 \mathrm{~h}\end{array}$ & (2) 15 photos + text & no \\
\hline
\end{tabular}

\subsection{Data Analysis}

This qualitative study utilized the deductive content analysis. The deductive approach explores the data based on the theory [48]. In this study, the theory of the relation between sensations and perceptions [16] (see Section 1) was applied. The data were classified in five sensations including all the reflections referring to visioning, hearing, smelling, haptic touching, kinesthetic touching and tasting. The perceptions, entire verbal expression implying various sensations were categorized.

The content analysis aims to attain the phenomenon by the outcome of the analysis. Next the data were coded based on the content [49]. The analysis process included three steps. Some of the expressed perceptions belonged to several categories. For example, the perception " ... lesser celandine reminded me about manor gardens ... " was included both into a memories category and into a human-environment interaction category. The sticker map notes were analyzed using the same categorization as the data gained by arts-based methods (Figure 3). 


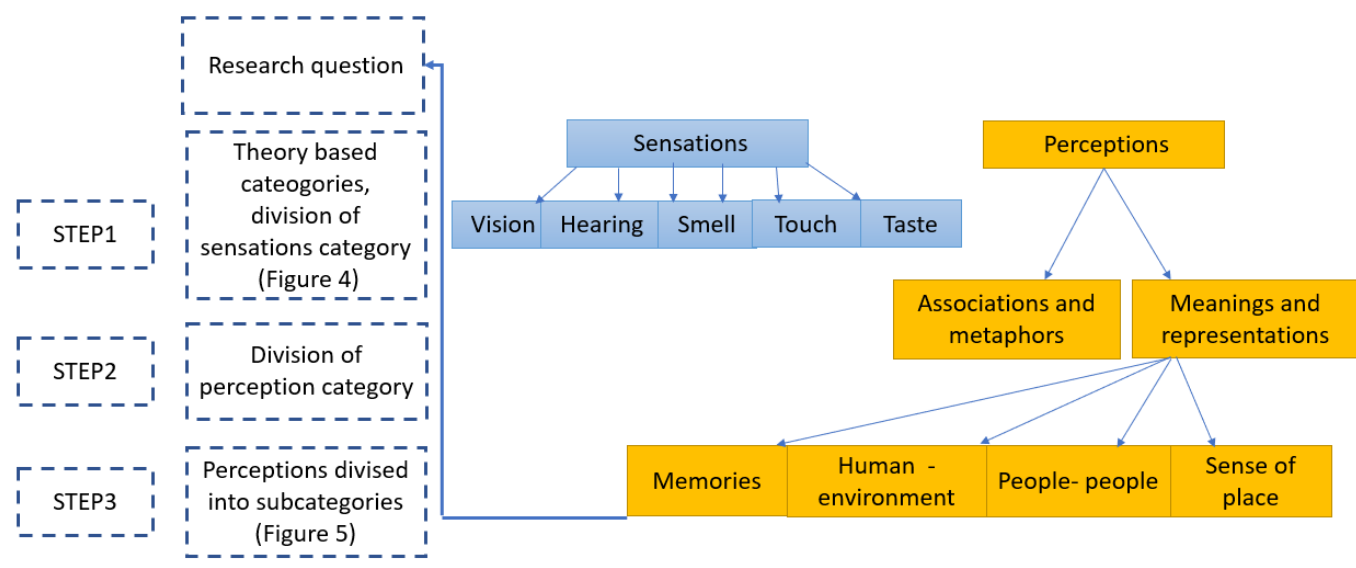

Figure 3. The content analysis included three steps. After the division (Step 1) between sensations and perceptions, the perceptions were categorized (Step 2) into associations and metaphors and meanings and representations and after that (Step 3) a meanings and representations category was divided into four (a memories, a human-environment, a people-people and a sense of place category). The categorization aims to answer the research question.

Step 1: First, three different ways were needed to transcribe the data. Expressions of the recorded conversations related to sensations and perceptions were written down. Then the photos and text of perceptions were interpreted and written down and then written stories were read and turned into perceptions. Thereafter, expressions of sensations were coded and divided among five sensations categories: vision, hearing, smell, touch and taste. The division of the sensations was ready. Whereas perceptions were entire expressions and separated from thinking, imagining and dreaming [18] (see Introduction) and so were analyzed further.

Sensation: Smell Perception: " . . not yet smell of bird cherry, but smell of water ... "

Consequently, the categories were the following: sensations and perceptions (Figure 3).

Step 2: Next, the perceptions category was divided in two as follows: (1) an association and metaphors category and, (2) a meanings and representations category. The perceptions that were not associations and metaphors constituted the latter category. Associations were considered to be expressions having connections to ideas, feelings and events and metaphors were considered to be linguistic phrases [50]. Consequently, the categories were the following: associations and metaphors and meanings and representations (Figure 3).

Associations "... a miracle of awakening nature ... "

and metaphors: ". . . a branch like a poem ..."

Meanings and representations: "... experience to see birds ..."

Step 3: At this phase the division formed new categories under a meanings and representations category based on the content analysis, i.e., unequivocal expressions about human-environment interaction were categorized under that category whereas memory expressions or expressions about relations with other people were categorized under other categories (Figure 3).

Human-environment: " ... smell of clean air", " . . trees shade ... "

Memories: " ... a robin bird made me feel home ... "

People-people: " ... people enjoying warm weather together ... "

Consequently, the categories were first the following: a memories category, a humanenvironment interaction category, and a people-people relation category. Additionally, the revision produced a category which we named sense of place. The theory of a sense of place is known in architecture, in sociology in environmental psychology referring the place attachment and place meaning held by an individual or a group [51]. These sense-of-place perceptions were included under that category.

Sense of place: " ... an Amor bridge ..." ", ... a place with memories ... "

An association and metaphors category was not revised (Figure 3). 


\section{Results}

The data analysis resulted in a total number of 113 sensations and 120 perceptions that the arts-based methods facilitated (Figure 4). The study exploited interactive and individual reflections and provided four combinations with the arts-based methods. The reference, i.e., the sticker map, was the fifth. The number of the categorized perceptions was greater than the number of the total perceptions due to content that belonged to several categories (Figure 5).

\begin{tabular}{|c|c|c|c|c|c|c|c|}
\hline \multirow{2}{*}{$\begin{array}{l}\text { Methods of } \\
\text { capturing and } \\
\text { reflecting }\end{array}$} & \multicolumn{5}{|c|}{ QUANTITY OF SENSATIONS } & \multirow[b]{2}{*}{ TASTE } & \multirow{2}{*}{$\begin{array}{l}\text { TOTAL QUANTITY OF } \\
\text { PERCEPTIONS }\end{array}$} \\
\hline & VISION & HEARING & SMELL & $\begin{array}{l}\text { TOUCH haptic } \\
\text { (humidity, } \\
\text { temperature, ground } \\
\text { touch) }\end{array}$ & $\begin{array}{l}\text { TOUCH kinesthetic } \\
\text { (perceived through } \\
\text { movement) }\end{array}$ & & \\
\hline $\begin{array}{l}\text { Capturing: Drifting } \\
\text { Reflecting: Conversation }\end{array}$ & 27 & 11 & 4 & 6 & 11 & - & 40 \\
\hline $\begin{array}{l}\text { Capturing: Theatrical } \\
\text { images } \\
\text { Reflecting: Conversation }\end{array}$ & - & - & - & - & - & - & 19 \\
\hline $\begin{array}{l}\text { Capturing: Drifting } \\
\text { Reflecting: Photos/text }\end{array}$ & 1 & 2 & - & 2 & 3 & - & 14 \\
\hline \multirow{2}{*}{$\begin{array}{l}\text { Capturing: Drifting } \\
\text { Reflecting: Story }\end{array}$} & 21 & 7 & - & 2 & 16 & - & 47 \\
\hline & 49 & 20 & 4 & 10 & 30 & _- & \\
\hline Sticker map & - & - & - & - & - & - & 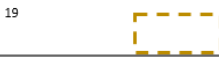 \\
\hline
\end{tabular}

Figure 4. Sensations and perceptions described by the quantitative columns as ascertained by the different method combinations. Several arts-based methods were used to capture and reflect perceptions, while sticker map method was used as a reference.

\begin{tabular}{|c|c|c|c|c|c|c|}
\hline \multirow{3}{*}{$\begin{array}{l}\text { Methods of } \\
\text { capturing and } \\
\text { reflecting }\end{array}$} & \multirow{3}{*}{$\begin{array}{l}\text { TOTAL QUANTITY } \\
\text { OF SENSATIONS }\end{array}$} & \multicolumn{5}{|c|}{ QUANTITY AND SUBCATEGORIES OF PERCEPTIONS } \\
\hline & & \multirow{2}{*}{$\begin{array}{l}\text { ASSOCIATIONS } \\
\text { AND } \\
\text { METAPHORS }\end{array}$} & \multicolumn{4}{|c|}{ MEANINGS AND REPRESENTATIONS } \\
\hline & & & $\begin{array}{l}\text { HUMAN- } \\
\text { ENVIRONMENT }\end{array}$ & MEMORIES & PEOPLE-PEOPLE & SENSE OF PLACE \\
\hline $\begin{array}{l}\text { Capturing: Drifting } \\
\text { Reflecting: Conversation }\end{array}$ & 59 & 4 & 14 & 8 & 10 & 9 \\
\hline $\begin{array}{l}\text { Capturing: Theatrical } \\
\text { images } \\
\text { Reflecting: Conversation }\end{array}$ & - & 4 & 5 & 4 & 15 & 6 \\
\hline $\begin{array}{l}\text { Capturing: Drifting } \\
\text { Reflecting: Photos/text }\end{array}$ & 8 & 8 & 4 & - & 2 & - \\
\hline \multirow[t]{2}{*}{$\begin{array}{l}\text { Capturing: Drifting } \\
\text { Reflecting: Story }\end{array}$} & 46 & 6 & 31 & 2 & 2 & 20 \\
\hline & & 22 & 54 & 14 & 29 & 35 \\
\hline Sticker map & - & - & 1 & - & 3 & 11 \\
\hline
\end{tabular}

Figure 5. The relative number of sensations and perceptions facilitated by arts-based methods and by the sticker map method. Several arts-based methods were used to capture and reflect perceptions. The perceptions enabled by arts-based methods comprised associations and metaphors, and under meanings and representations the categories were: human-environment including all related perceptions of this issue. The other categories comprise also human-environment interaction, but also other types of perceptions categorized as memories, people-people relations, and responses related to the places. The sticker map ascertained perceptions related to human-environment interaction, to people and places.

\subsection{Sensations and Related Perceptions}

The number of vision sensations (49) was the greatest among the various sensations. The second greatest group was touch sensations (40), divided into haptic touch (10) and kinesthetic (30). Hearing sensations (20) and smell sensations (4) were least represented and taste sensations did not occur in any cases (Figure 4).

The gained sensations depended on the method. The greatest number of vision sensations was related to drifting and both to interactive and individual reflection methods, 
enabling also the greatest number of perceptions. When the method (drifting and conversation) provided four sensations and the other method (drifting and story) three, both methods enabled the second greatest number of kinesthetic touch sensations after vision sensations. Drifting with individual reflection method (photos and text) produced visual outcomes and only a small number of sensations were ascertained. The theatrical images method with interactive conversations did not provide any sensations, however both the two last methods and the sticker map provided the same relative number of perceptions. The sticker map did not provide any sensations.

\subsection{Perceptions}

Five perception subcategories were ascertained. One category was the associations and metaphors category, and under the meaning and representations were found the four other categories: human-environment interaction, memories, people-people relations and place related perceptions which was named 'sense of place' category. Human -environment perceptions category excluding association or metaphors included all human-interaction perceptions. They represented the largest group and also most sensations were ascertained related to human-environment perceptions (Figure 5).

\subsubsection{Associations and Metaphors}

Associations and metaphors (22) were captured by all arts-based methods combinations (Figure 5). Participants associated connections mostly to natural elements, such as water features and landscape, i.e., a pond was connected to a calm lake landscape and a certain place to an event abroad. Furthermore, sounds were typical associations, i.e., certain sounds were related to harbor landscape sounds. Metaphors were such as "the robin bird made me feel at home", "a bird made plops when diving to get a fish", "branches waved to welcome us". "Birches are bathing in the sun and moss is sleeping", "human noise from the city is seeking a way to the forest". As unique phrases they described subjective emotions, attitudes and values.

\subsubsection{Human-Environment Interaction}

This category included perceptions (54) which were interpretable as human-environment interaction perceptions (Figure 5). They expressed how landscape elements such as water, trees, ground and scenes were recognized and valued, however all expressions were not only subjective and emotional, but also declaratory: “ . . old materials refer to the landscape of the park ...". Most of the perceptions related to surrounding nature environment, such as bird singing and " . . a miracle of nature ...", "... waiting for nature to awake ...".

\subsubsection{Memories}

The memory perceptions (14) were connected to certain places, nature observations evoke memories and mostly they awoke from noticing a plant or hearing a bird (Figure 5). Additionally, memories related to haptic touch, i.e., walking barefoot on wooden ships was reported.

Memories were also subjective. The emotions were not so obvious compared to associations and metaphors, however positive or negative feelings were interpretable out of some memory perceptions. Some were also informative " ... the bird box remains that this park is not only for people..."

\subsubsection{People-People Relation}

This category included perceptions (29) related to other people (Figure 5). In all cases perceptions indicated that activities and attendance of other people created a positive atmosphere. Many perceptions were about one or two people, which were related to subjective perceptions, however noticing other people in different places created safe and permissible atmosphere. "I recognized people on the pier, now I know I can go there ... ", " . . children were laughing when they tried to catch a bee ... ". Additionally, a great 
number of relations was ascertained to the relationships between people: "if you have a bad feeling, you can go out to meet others and you get a good feeling", "there are always friends out there and we play football together, also 50-year old people play with us". In other cases the informants emphasized several places where human interactions take place: "a love bridge", "a pier" and "a lakeside".

\subsubsection{Sense of Place}

The perceptions (35) were related to specific places in the parks (Figure 5). The physical places acquired meanings when perceptions were articulated by participants. In addition to describing the physical places, they also had subjective meanings through names given by local people such as "The Eye of Alis" and "Bananahill".

\subsection{Dependence on Method to Capture Perceptions}

The arts-based methods in the two workshops 2017 were offered to more people than finally utilized the methods. In Pikku-Vesijärvi Park 11/54 visitors chose the drifting method and in Rautkallio Park 3/15 visitors chose the theatrical images method. The visitors considered these to be new kinds of methods compared to conventional inquiry methods used.

The sticker map method in one workshop was utilized by 43 people. It generated a few perceptions about human-environment interactions (5), about people's relations with each other (3) and additionally a number of perceptions (11) referred to the importance of place: "peaceful", "nice view", "the place with sculptures" (Figure 5). However, the largest number of the notes (18) were suggestions to improve certain areas or create events, i.e., more related to the future.

\section{Discussion}

Our findings showed that the more sensations were ascertained the more perceptions were enabled. The arts-based methods captured associations and metaphors, which included only unique and emotional expressions. Other captured perceptions were humanenvironment interactions, memories, relations between people and place related perceptions, and included also emotional expressions. The human-environment perceptions were most frequent as enabled by all methods. The methods favored different kinds of perceptions. The sticker map provided no sensations and a relatively smaller number of perceptions than the arts-based methods.

\subsection{Potential of Arts-Based Methods to Capture Perceptions of Urban Open Spaces}

The results demonstrate differences of the method combinations to capture perceptions. The reflection can be interactive or individual to gain perceptions depending on the situation. When utilized they provide many perceptions as they are described by one person to another. Individual outcomes in the form of written stories also give access to perceptions. Individual visual outcomes such as photos and texts do not always provide enriched perceptions but this mode of reflection is useful to implement digitally.

Since associations and metaphors were not the only gained unique perceptions, artsbased methods appeared to also foster memories and other emotional perceptions. This questions professional practices by identifying different values as found by Pässilä [52], i.e., the results indicated people's inclusive role, contrary to non-arts-based methods such as giving feedback as users or non-owners. The reference method, i.e., the sticker map, stimulated people to mostly express ideas for improvements in the park, reflecting an objective view, whereas the results of using arts-based methods proved that the role of citizens was subjective.

This study also provided unpredictable perceptions about relations to other people or places. Perceptions about people or relations between people revealed information about permissibility and feelings, which are not pursued by commonly collected information regarding urban open spaces. The place related perceptions were local knowledge, and these 
emotional connections to specific natural spaces and to cultural elements expressed feeling of belonging, which deepen understanding about relational interactions between humans and the environment [53]. To acknowledge place-related perceptions gives a good base to understand human-environment transformation through place-related behavior [54] or beyond anthropocentric approaches [55]. Sense of place in this study was a free encounter with the landscape as ascertained during the drifting or it could be a deeper connection as found with the theatrical images method. However, the potential of the sense of place to be a transformative factor towards sustainability by developing knowledge [56] benefits from the understanding that both drivers and barriers to positive change may be linked with an individual experience about sense of place $[57,58]$.

All methods captured perceptions, but not all methods captured sensations. However, the sensations also provided information about urban open spaces. The kinesthetic touch sensations, which the drifting method enabled required multisensory and embodied experience, which can increase the capacity for people to be woven into sustainability [35]. Hearing sensations contributed to information about human-environment interaction, which recounts about different values such as cultural and recreational values about urban open spaces [59]. Consequently, as the results indicate that sensations foster perceptions it is crucial to enable and recognize them regarding urban open spaces.

\subsection{Perceptions in Fostering Sustainability Transition}

As the results confirmed arts-based methods enabled human-environment interaction and facilitated human and environmental relations between people which may act as drivers to sustainability transition [60]. Therefore, local perceptions about behavior, social cohesion, and interactions with nature and the environment $[53,61]$ are important to recognize and acknowledge in discourse about urban open spaces. Additionally, perceptions about the environment conveyed local ecological knowledge, which, according to Folke [62], is a navigating point from a narrow interpretation of ecosystems towards a broader socio-ecological understanding. Such perceptions also break the dichotomy of sustaining nature either for humans or for its own sake, which is contemporary social change to understand environmental challenges [63].

Sustainability-driven management of urban open spaces requires acknowledging the subjective expressions of both individual and social experiences that emerge from human interaction with the biophysical environment and to use this knowledge to promote a transition towards sustainable open space management. Parks have been challenged to react to changes in society in the past and contemporary change requires responses to biodiversity loss, stormwater management concerns, carbon sequestration and urbanization. In this change towards ecological and sustainable urban open spaces, nature experiences and allowing subjective significances to become visible when they can be articulated freely and spontaneously, diversifying experiences may foster human-nature connection.

Consequently, the arts-based information captured in this study provided subjective knowledge on cultural, well-being, recreation and quality of life issues, which according to present-day research $[64,65]$ (p. 581) enables sustainability aspects to become visible and thus increase understanding about sustainable transition. Therefore, when such information is gained about urban open spaces, it is important to acknowledge all perceptions about the local environment. The method combinations used have provided understanding for applying and developing arts-based methods in practice for the management of urban open spaces.

\subsection{Reliability of the Findings}

The case study comprising two parks and three workshops with four arts-based method combinations of capturing and reflecting people's sensations and perceptions about urban open spaces represented an initial attempt to explore the usefulness of artsbased methods. The sticker map method enabled the comparison of the arts-based methods. The number of participants in each workshop was limited, but the participants varied 
among the workshops. No attempt towards generalization of the case study findings was performed and therefore, demographic information about the participants was not collected. The qualitative analysis of the data was triangulated among several researchers to reduce a potential bias. The results deserve to be confirmed and enriched with a greater number of participants and arts-based methods.

Cultural background influences subjective perceptions and the actions of individuals [66]. Perceptions are culture-dependent which points to the potential of arts-based methods in this context i.e., to surface perceptions in ways that go beyond those accessible in conventional surveys. When arts-based methods are used in different urban open places, the methods can be tuned to consider the culture of specific places for particular societal groups, for example, activity areas for young people or neighborhood environments for the elderly.

\section{Conclusions}

The arts-based methods used in this study contributed to the generation of subjective, emotional and unique perceptions that indicate environmental and ecological literacy. The methods can provide a new approach beyond traditional technical-based analyses, which do not consider ecosystems and non-human species as co-existing with humans, and help orientate research to a more-than-human perspective to realize inclusiveness with the environment [67]. The method combinations were found to be suitable for use in workshops to gain information about urban open spaces. While enhancing citizens' experiences and making them visible through diversifying methodology, richer subjective information can be obtained beyond that of routine inquiries.

The socio-ecological dimension of arts-based methods offers a novel approach for co-creation processes between individuals, organizations and communities on the basis of spontaneous and non-evaluative communication. This communication and dialogue will require new attitudes and skills from both people and management organizations. Future research should consider how perceptions could be exploited in a continuous urban open space management process that takes full account of people's subjective and emotive needs promoting sustainability transition.

Author Contributions: Conceptualization, S.S., H.K., A.P., A.O. and C.H.; methodology, S.S., A.P., A.O. and C.H.; validation, S.S., H.K. and A.P.; formal analysis, S.S., H.K. and A.P.; investigation, S.S., H.K. and A.P.; writing — original draft preparation, S.S.; writing—review and editing, S.S., H.K., A.P., A.O. and C.H.; visualization, S.S.; supervision, H.K. and A.P. All authors have read and agreed to the published version of the manuscript.

Funding: This study was financially supported through Maiju and Yrjö Rikala's Garden Foundation: 0000.

Institutional Review Board Statement: Ethical review according Finnish National Board on Research integrity was conducted before this study and there was no need for an approval of the Institutional Review Board.

Informed Consent Statement: Informed consent was obtained from all subjects involved in the study. No demographic information was collected and participants cannot be identified.

Data Availability Statement: Not applicable. Preserved by S.S.

Conflicts of Interest: The authors declare no conflict of interest. The founding sponsors had no role in the design of the study; in the collection, analyses, or interpretation of data; in the writing of the manuscript, or in the decision to publish the results.

\section{References}

1. United Nations Sustainable Development Goals Report. Available online: https://www.un.org/development/desa/ publications / the-sustainable-development-goals-report-2018.html (accessed on 12 February 2020).

2. United Nations Sustainable Development Goals. Available online: https:/ / www.un.org/sustainabledevelopment/ (accessed on 10 May 2021). 
3. Jansson, M.; Vogel, N.; Fors, H.; Dempsey, N.; Buijs, A.; Randrup, T.B. Defining Urban Open Space Governance and Management. In Book Urban Open Space Governance and Management; Jansson, M., Randrup, T.B., Eds.; Routledge: London, UK, 2020 ; p. 12.

4. Taylor, H.A. Urban Public Parks, 1840-1900: Design and Meaning. Gard. Hist. 1995, 23, 201-221. [CrossRef]

5. Fischer, A.P. Landscape and Urban Planning Forest landscapes as social-ecological systems and implications for management. Landsc. Urban Plan. 2018, 177, 138-147. [CrossRef]

6. Jensen, M.B.; Persson, B.; Guldager, S.; Reeh, U.; Nilsson, K. Green structure and sustainability-Developing a tool for local planning. Landsc. Urban Plan. 2020, 52, 117-133. [CrossRef]

7. Fongar, C.; Aamodt, G.; Randrup, T.B.; Solfjeld, I. Does perceived green space quality matter? Linking Norwegian adult perspectives on perceived quality to motivation and frequency of visits. Int. J. Environ. Res. Public Health 2019, 16, 2327. [CrossRef]

8. Chiesura, A. The role of urban parks for the sustainable city. Landsc. Urban Plan. 2004, 68, 129-138. [CrossRef]

9. Jansson, M.; Lindgren, T. A review of the concept "management" in relation to urban landscapes and green spaces: Toward a holistic understanding. Urban For. Urban Green. 2012, 11, 139-145. [CrossRef]

10. Abson, D.J.; Fischer, J.; Leventon, J.; Newig, J.; Schomerus, T.; Vilsmaier, U.; Wehrden, H.; von Abernethy, P.; Ives, C.D.; Jager, N.W.; et al. Leverage points for sustainability transformation. Ambio 2017, 46, 30-39. [CrossRef] [PubMed]

11. Bennett, N.J.; Whitty, T.S.; Finkbeiner, E.; Pittman, J.; Bassett, H.; Gelcich, S.; Allison, E.H. Environmental Stewardship: A Conceptual Review and Analytical Framework. Environ. Manag. 2018, 61, 597-614. [CrossRef]

12. Shrivastava, P.; Ivanaj, V.; Ivanaj, S. Sustainable development and the arts. Int. J. Technol. Manag. 2012, 60, 23-43. [CrossRef]

13. Soga, M.; Gaston, K.J. Extinction of experience: The loss of human-nature interactions in a nutshell. Front. Ecol. Environ. 2016, 14, 94-101. [CrossRef]

14. Scott, A.; Carter, C.; Brown, K.; White, V. "Seeing is not everything": Exploring the landscape experiences of different publics. Landsc. Res. 2009, 34, 397-424. [CrossRef]

15. Hatfield, G. Sense Data, The Stanford Encyclopedia of Philosophy-Zalta, E.N. Zalta. Available online: https:/ / plato.stanford. edu/archives/fall2021/entries/sense-data/ (accessed on 3 October 2020).

16. Maund, B. Perception. In Central Problems of Philosophy; Shand, J., Ed.; Acumen: Chesham, UK, 2003; p. 20.

17. Lothian, A. Landscape, and the philosophy of aesthetics: Is landscape quality inherent in the landscape or in the eye of the beholder? Landsc. Urban Plan. 1999, 44, 177-198. [CrossRef]

18. Jacobs, M. The production of mindscapes: A comprehensive theory of landscape experience. 2006. Available online: https: / / edepot.wur.nl/40182 (accessed on 5 May 2020).

19. Swanwick, C. Society's attitudes to and preferences for land and landscape. Land Use Policy 2009, 26, 62-75. [CrossRef]

20. Stobbelaar, D.J.; Pedroli, B. Perspectives on landscape identity: A conceptual challenge. Landsc. Res. 2011, 36, 321-339. [CrossRef]

21. Bell, S. Landscape: Pattern, Perception and Process; Routledge: London, UK, 2012; p. 40.

22. Antrop, M.; van Eetvelde, V. Landscape Perspectives: The Holistic Nature of Landscape; Springer: Amsterdam, The Netherlands, 2020 ; p. 436.

23. Qiu, L.; Lindberg, S.; Nielsen, A.B. Is biodiversity attractive? On-site perception of recreational and biodiversity values in urban green space. Landsc. Urban Plan. 2013, 119, 136-146. [CrossRef]

24. Palliwoda, J.; Kowarik, I.; von der Lippe, M. Human-biodiversity interactions in urban parks: The species level matters. Landsc. Urban Plan. 2017, 157, 394-406. [CrossRef]

25. Wang, Y.; Kotze, D.J.; Vierikko, K.; Niemelä, J. What makes urban greenspace unique-Relationships between citizens' perceptions on unique urban nature, biodiversity, and environmental factors. Urban For. Urban Green. 2019, 42, 1-9. [CrossRef]

26. Barone, T.; Eisner, W.E. Arts Based Research; Sage: Thousand Oaks, CA, USA, 2012; p. 168.

27. Leavy, P. Introduction to Arts-Based Methods. In Handbook of Arts-Based Research; Leavy, P., Ed.; Guilford Press: New York, NY, USA, 2018; p. 4.

28. Adams, J.; Owens, A. Learning through Arts-Based Research; Intellect \& Chicago Press: Bristol, UK, $2021 ;$ p. 6.

29. Benmergui, R.; Owens, A.; Passila, A. Beyond Text: Arts Based Methods for Research, Assessment and Evaluation, Erasmus + EU: Beyond Text Partnership. Available online: https:/ / beyondtext.weebly.com/ (accessed on 5 March 2020).

30. Gerber, N.; Biffi, E.; Biondo, J.; Gemignani, M.; Hannes, K.; Siegesmund, R. Arts-Based Research in the Social and Health Sciences: Pushing for Change with an Interdisciplinary Global Arts-Based Research Initiative. Forum Qualitative Sozialforschung. Available online: https:/ / www.qualitative-research.net/index.php/fqs/article/view/3496 (accessed on 3 March 2021).

31. Kytta, M.; Broberg, A.; Tzoulas, T.; Snabb, K. Towards contextually sensitive urban densification: Location-based softGIS knowledge revealing perceived residential environmental quality. Landsc. Urban Plan. 2016, 113, 30-46. [CrossRef]

32. Vich, G.; Marquet, O.; Miralles-Guasch, C. The scales of the metropolis: Exploring cognitive maps using a qualitative approach based on SoftGIS software. Geoforum 2018, 88, 49-56. [CrossRef]

33. Bussey, M. Embodied education: Reflections on sustainable education. Int. J. Environ. Cult. Econ. Soc. Sustain. 2008, 4, 139-148. [CrossRef]

34. Kuepers, W.M. "Trans + form": Leader-and followership as an embodied, emotional and aesthetic practice for creative transformation in organisations. Leadersh. Organ. Dev. J. 2011, 32, 20-40. [CrossRef]

35. Kuepers, W. Phenomenology of embodied and artful design for creative and sustainable inter-practicing in organisations. J. Clean. Prod. 2016, 135, 1436-1445. [CrossRef]

36. National Land Survey of Finland. Map Site Areal Photo Map; Modified by S. Suomalainen; National Land Survey of Finland: Helsinki, Finland, 5 March 2021. 
37. Debord, G. Theory of the Dérive. Available online: https://www.cddc.vt.edu/sionline/si/theory.html (accessed on 5 February 2020).

38. Trier, J.; Debord, G. The Situationist International, and the Revolutionary Spirit; BRILL: Leiden, The Netherlands, 2019 ; pp. 53-55.

39. Ingold, T. Culture on the ground: The world perceived through the feet. J. Mater. Cult. 2004, 9, 315-340. [CrossRef]

40. Oxford University. Available online: https://www.oxfordreference.com/view/10.1093/oi/authority.20110803095713704 (accessed on 8 February 2020).

41. Owens, A.; Holtham, C. The Derive: Learning Through Walking About. Presentation 2003. University of Chester and Cass Business School of London City University: London, UK, 2003.

42. Poole, S.; Scott, C.; Marichalar-Freixa, E. Psychogeography and Well-Being. In Good Health and Well-Being. Encyclopedia of the UN Sustainable Development Goals; Filho, W., Wall, T., Azul, A.M., Brandli, L., Özuyar, P.G., Eds.; Springer: Cham, Switzerland, 2020.

43. Boal, A. Theatre of the Oppressed; Pluto Press: London, UK, 1979.

44. Pässilä, A. Reflexive Model of Research-Based Theatre-Processing Innovation at the Crossroads of Theatre, Reflection, and Practice-Based Innovation Activities; Lappeenranta University Press: Lappeenranta, Finland, 2012.

45. Pässilä, A.; Oikarinen, T.; Kallio, A. Creating dialogue by storytelling. J. Workplace Learn. 2013, 25, 159-177. [CrossRef]

46. Pässilä, A.H.; Oikarinen, T.; Harmaakorpi, V. Collective voicing as a reflexive practice. Manag. Learn. 2015, 46, 67-86. [CrossRef]

47. Kyttä, M.; Kaaja, M. Vuorovaikutteisen Suunnittelun Ja Ympäristön Tutkimuksen Metodipaketti; Yhdyskuntasuunnittelun Tutkimus-ja Koulutuskeskus YTK: Espoo, Finland, 2001.

48. Elo, S. The qualitative content analysis process. J. Adv. Nurs. 2008, 62, 107-115. [CrossRef]

49. Mayring, P. Qualitative Content Analysis. Forum Qual. Soc. Res. 2000, 1, 159-176. [CrossRef]

50. Sam, M.S. Associaton in PsychologyDictionary.org. Available online: https://psychologydictionary.org/association/ (accessed on 28 July 2021).

51. Cross, J. What is Sense of Place? Conference paper. In Proceedings of the 12th Headwaters Conference, Gunnison, CO, USA, 2-4 November 2001.

52. Pässilä, A.; Owens, A.; Pulkki, M. Learning Jam: An evaluation of the use of arts-based initiatives to generate polyphonic understanding in work-based learning. High. Educ. Ski. Work. Based Learn. 2016, 6, 178-192. [CrossRef]

53. Ives, C.D.; Giusti, M.; Fischer, J.; Abson, D.J.; Klaniecki, K.; Dorninger, C.; Laudan, J.; Barthel, S.; Abernethy, P.; Martín-López, B.; et al. Human-nature connection: A multidisciplinary review. Curr. Opin. Environ. Sustain. 2017, 26-27, 106-113. [CrossRef]

54. Masterson, V.A.; Stedman, R.C.; Enqvist, J.; Tengö, M.; Giusti, M.; Wahl, D.; Svedin, U. The contribution of sense of place to social-ecological systems research: A review and research agenda. Ecol. Soc. 2017, 22, 49. [CrossRef]

55. Randrup, T.B.; Buijs, A.; Konijnendijk, C.C.; Wild, T. Moving beyond the nature-based solutions discourse: Introducing naturebased thinking. Urban Ecosyst. 2020, 23, 919-926. [CrossRef]

56. Colley, K.; Craig, T. Natural places: Perceptions of wildness and attachment to local greenspace. J. Environ. Psychol. 2019, 61, 71-78. [CrossRef]

57. Stedman, R.C. Sense of place as an indicator of community sustainability. For. Chron. 1999, 75, 765-770. [CrossRef]

58. Mastura, N.; Mohammad, N.; Saruwono, M.; Said, S.Y.; Ahmad, W. A Sense of Place within the Landscape in Cultural Settings. Procedia Soc. Behav. Sci. 2013, 105, 506-512. [CrossRef]

59. Pijanowski, B.C.; Farina, A.; Gage, S.H.; Dumyahn, S.L.; Krause, B.L. What is soundscape ecology? An introduction and overview of an emerging new science. Landsc. Ecol. 2011, 26, 1213-1232. [CrossRef]

60. Wolfram, M. Conceptualizing urban transformative capacity: A framework for research and policy. Cities 2016, 51, 121-130. [CrossRef]

61. Kabisch, N.; Qureshi, S.; Haase, D. Human-environment interactions in urban green spaces-A systematic review of contemporary issues and prospects for future research. Environ. Impact Assess. Rev. 2015, 50, 25-34. [CrossRef]

62. Folke, C. Resilience: The emergence of a perspective for social-ecological systems analyses. Glob. Environ. Chang. 2006, 16, 253-267. [CrossRef]

63. Cote, M.; Nightingale, A.J. Resilience thinking meets social theory: Situating social change in socio-ecological systems (SES) research. Prog. Hum. Geogr. 2012, 36, 475-489. [CrossRef]

64. Schulz, K.; Kawamura, T.; Geithner, S. Enabling sustainable development in healthcare through art-based mediation. J. Clean. Prod. 2017, 140, 1914-1925. [CrossRef]

65. Schulz, K.; Mnisri, K. Pathways to Connect Creativity and Sustainable Development; PUN-Éditions Universitaires De Lorraine ARTEM OCC; ICN: Nancy, France, 2020; p. 581.

66. Lehman, D.R.; Chiu, C.; Schaller, M. Psychology and Culture. Annu. Rev. Psychol. 2004, 55, 689-714. [CrossRef] [PubMed]

67. Wolff, A.; Pässilä, A.; Knutas, A.; Vainio, T.; Lautala, J.; Kantola, L. The Importance of Creative Practices in Designing More-ThanHuman Cities. In Handbook of Smart Cities; Augusto, J.C., Ed.; Springer: Cham, Switzerland, 2021. [CrossRef] 